\title{
ORGANIZATIONAL GOVERNANCE ADAPTATION: WHO IS IN, WHO IS OUT, AND WHO GETS WHAT
}

\author{
PETER G. KLEIN \\ Baylor University and Norwegian School of Economics \\ JOSEPH T. MAHONEY \\ University of Illinois at Urbana-Champaign \\ ANITA M. MCGAHAN \\ University of Toronto \\ CHRISTOS N. PITELIS \\ Abu Dhabi University and Brunel University London
}

\begin{abstract}
Governance gives life to an organization by establishing the rules that shape organizational action. Structures of governance rest on stakeholder engagement, particularly on how stakeholders assess the prospects for earning a return by committing their specialized resources to the organization. Once formalized, governance structures and processes can resist change. Yet, under special circumstances, some stakeholders that are $\alpha$ party to an organization may seek to adapt governance in response to changes in the external environment that surrounds the organization. Adaptation often requires renegotiation: who has claims on the organization and who gets what? In this article we analyze the relationship between the institutional change that drives adaptation and the outcome of renegotiation. We draw on institutional economics and organization theory to identify four pathways of governance adaptation: continuity, architectural change, enfranchisement change, and redistribution. We call for further theoretical and empirical research on governance adaptation and its implications for organizational value creation and capture.
\end{abstract}

Forming an organization requires establishing rules about who will be in charge, how leadership turnover will occur, who will be involved in critical decisions, how gains will be distributed, and who will bear the risk of failure. These rules, which make up the organization's governance structure, give life and continuity to the organization as an entity separate from its members and from other persons and entities. To foster cooperation, governance structures include safeguards to protect the interests and investments of key stakeholders

\footnotetext{
We thank former associate editor Don Lange and three exceptionally helpful reviewers for their questions, criticisms, and suggestions and Lyda Bigelow, Gary Libecap, and Anne Parmigiani for feedback. We are also grateful to conference and workshop participants at the Allied Social Sciences Association, Atlanta Competitive Advantage Conference, Academy of Management annual meeting, Strategic Management Society, International Society for New Institutional Economics, London Business School, New York University's GovLab, Oklahoma State University, and the University of Toronto for useful comments. Author names are listed in alphabetical order.
}

(Blair \& Stout, 1999; Klein, Mahoney, McGahan, \& Pitelis, 2013). For example, the rules on how a CEO is selected, what the length of the CEO's term is, how key decisions are made, and how compensation is determined are difficult to change, even by the top management team, without consultation, due process, and negotiation (Cyert \& March, 1963; Pfeffer \& Salancik, 1978).

When do changes in the external environment (EE) compel adaptation in an organization's governance structure? To make this question tractable, we focus in this article on changes originating in the institutional environment (IE). While the EE generally includes technology, demand, and institutional shocks that affect the firm's behavior and performance, the IE refers to the specific formal and informal legal, political, and social structures and processes in the EE that frame organizational governance structures (Mahoney, 2005; North, 1990; Williamson, 2000). We are particularly interested in how firms respond to unanticipated change in the IE. 
For example, De Beers, the South African mining company, operated historically under governance rules designed under and aligned with apartheid. The IE changed in the early 1990s with the end of apartheid and the election into power of Nelson Mandela's African National Congress (Rantete, 1998). Subsequently, new regulations were implemented mandating that corporations enfranchise blacks in ownership, leadership, and operational decisions. De Beers responded first by adapting its strategy and operations to the new IE, appointing a black managing director in late 2005 , and offering equity to black investors (Reed, 2005). This led to newly enfranchised stakeholders with different control and ownership rights - $\alpha$ change in the firm's governance structure. Adaptation was successful, in part, because the new and old enfranchised stakeholders appeared to share the overriding objective of rebuilding the South African economy and society. In the face of radical legal and social change, De Beers adapted to ensure the organization's survival as South Africa was transformed.

In other cases firms take different paths in response to changes in the IE. As explained by Chandler (1962), many firms during the 1920s either failed or were slow to respond to advances in telecommunications and railroads that enabled greater levels of diversification and decentralization. The pioneering firms that adopted the new multidivisional or "M-form" structure-most notably, General Motors (GM), DuPont, Standard Oil, and Sears-had access to strategies that led them to become the largest and most successful companies of their era.

Modern examples of change in the IE include the adoption of international climate-change agreements, the implementation of patent laws, and new international and domestic public policy regimes. In some cases government and private actors attempt to influence organizations directly (e.g., to include black citizens in the governance of organizations in postapartheid South Africa). In other cases the effects are indirect (e.g., when cancellation of a pending international trade agreement allows a firm to make decisions without considering foreign actors). When these IE changes are substantial, they compel change not only in firm's strategies and processes but also in the governance structure that surrounds those strategies and processes.

Quoting Chester Barnard (1938), Williamson described adaptation as "the central problem of organization" (1996: 299). Markets adapt continuously, with adjustments coordinated by the price system within a given institutional framework (Hayek, 1945). In an organization, however, adaptation is more difficult since it requires a degree of central coordination and control (Barnard, 1938; Williamson, 1996). ${ }^{1}$ The problem becomes more complex when required adaptation challenges the authority of the organization's core stakeholder groups. This situation of adaptation in governance raises specific challenges about how enfranchised stakeholders protect and pursue their interests and what pathways to change become available, given the interplay between different stakeholder groups.

Scholarship in management, corporate finance, and contract economics has substantially addressed the nature and effects of governance (Foss \& Mankhe, 2002; Hendry \& Kiel, 2004; Williamson, 1996), but researchers have not dealt as fully with issues of governance change. A key fact about governance is that governance arrangements typically include procedures about how the firm's assets will be liquated in cases of financial distress and how the residual value will be distributed to shareholders. However, comprehensive organizational failure is a dramatic and costly event that stakeholders seek to avoid except in exceptional circumstances. A more effective, efficient, and valuable alternative is to change the governance structure of an organization in response to a change in the IE. Under external pressure, key stakeholders may renegotiate the firm's governance arrangements to support the organization's survival, even if this leaves them worse off than before. For instance, a firm's founders may agree to the subordination of their original ownership shares in exchange for investment capital that keeps the firm going (Rajan, 2012). Unions may agree to renegotiate binding wage agreements or benefit packages. In each instance a stakeholder group accepts a worse deal as superior to no deal, and liquidation is averted. The threat to the firm's survival leads to renegotiation, rather than to the distribution of residual value to shareholders.

The value of adopting the firm's governance structure is particularly high when the external stress comes from unanticipated changes to the

\footnotetext{
${ }^{1}$ Williamson (1991a) referred to these as "autonomous" and "cooperative" adaptation, respectively (see also Williamson, 199lb).
} 
IE. While the role of the EE has been recognized as fundamental to strategic management since Porter (1980), interest in change in the IE has recently intensified (Henisz, 2000; North, 1990). This interest is motivated, in part, by a recognition that failure to adapt to IE changes may threaten the ongoing existence of the organization. We do not seek to explain all aspects of governance but, rather, focus specifically on the process of adaptation itself. Similarly, we are not investigating all elements of organizational change but those specific changes instead that an organization's governing stakeholders negotiate, accept, and act on in the face of threats to the entire organization's existence.

As we explain below, several important recent examples of organizational restructuring and evolution are best understood as governance adaptation in response to changes in the IE. We discuss architectural change at De Beers, Dollar General, and Enron; enfranchisement change in the pharmaceutical industry; redistribution by companies faced with environmental disaster; and continuity at JPMorgan Chase after the 2007-2008 financial crisis. These examples illustrate that firms do not respond to IE changes in the same way.

To understand the pathways of governance adaptation, we integrate insights from organization theory (Scott, 2008) with those from institutional economics (Williamson, 1993). Like Scott, we view organizations as "coalitions of shifting interest groups that develop goals by negotiation; the structure of the coalition, its activities, and its outcomes are strongly influenced by environmental factors" (1987: 23; see also Scott, 2008). Our analysis deals with cases in which some agents can resist legitimate demands for adaptation following environmental change but where the ability to resist is limited. For instance, a CEO may not be able to control the process by fiat because the CEO's decision is outside the "zone of acceptance" (Barnard, 1938; Simon, 1947). The situations that we seek to analyze may put the CEO's role in jeopardy. Adaptation involves a complex negotiation or renegotiation among different enfranchised actors and groups about the governance authority and rewards.

In this conceptualization, organizations are open systems in which the relevant actors, such as the CEO, board members, employees, shareholders, and managers, compare the benefits and costs of the organization's existing governance structure to available alternatives. Adaptive responses to environmental change involve renegotiation among the key enfranchised actors, who try to maintain or improve on their prior interests and positions. However, achieving this outcome is almost never possible for all enfranchised actors. Negotiations may also proceed by threatening stakeholders who seek to avoid adoptation with future expulsion or reduction in status. Changing the governance structure of organizations requires the collective action of essential stakeholders to find a negotiated arrangement that each sees as superior to nonengagement.

Our framework begins with the institutional economics literature on collective action (Libecap, 1989; Olson, 1965; Ostrom, 1990). This literature considers how organizations emerge to coordinate the contributions of essential stakeholders (Alchion \& Demsetz, 1972; Grossman \& Hart, 1986). The canonical problem in this tradition is how the essential parties to value creation achieve agreement on the terms by which they will be governed organizationally. From organization contingency theory (Galbraith, 1973; Lawrence \& Lorsch, 1967; Scott, 1987), we hold that resilient organizations are those that better adapt to their environment. Our focus is on how organizational actors impede or facilitate adaptation following institutional change. In doing so we address these fundamental questions: Who is in, who is out, and who gets what under an adapted governance structure?

Our main contribution is the identification of four broad pathways of governance adaptation: continuity, architectural change, enfranchisement change, and redistribution. Before discussing these four pathways, we first define terms and establish the key ideas on which our argument rests. We then turn to conceptual background. Finally, we develop a series of theoretical claims linking these constructs.

\section{THEORY DEVELOPMENT}

The stakeholders in an organization's governance structure are those actors who control resources and capabilities that are essential to the organization's function and performance. As we explain below, governance adaptation may take place when a change in the IE threatens the core organizational rules on who within the organization makes decisions and who gets what. In other words, a shock to the IE compels governance adaptation when it changes the relevance of 
stakeholder resources and capabilities. Of course, many changes to personnel and practices do not constitute governance adaptation. An organization's employees, for example, may choose to exit if an authoritarion CEO declares terms that substantially exceed employees' zone of acceptance (Simon, 1947), but this is not governance adaptation unless the departures prevent the organization from functioning. Adapting organizational governance structures is difficult because some stakeholders may not want change even when a major institutional or social event-for example, the overthrow of apartheid in South Africa, the threat of climate change, or the rise of social media-requires change and motivates other internal actors to pursue such change.

\section{Key Terms and Concepts}

Governance structures. Governance structures are the formal and informal rules and procedures that control resource accumulation, development, and allocation; the distribution of the organization's production; and the resolution of the conflicts of interest associated with group behavior (Blair \& Stout, 1999; Chandler, 1962; Williamson, 1985). General rules arise from commercial codes and corporate statutes, but owners and creditors can often specify unique rules via the company charter, articles of incorporation, and similar documents (Hansmann, 2006). Less formal rules arise from custom or emerge as part of the organization's culture to shape processes and routines. Collectively, governance rules establish the organization as an entity distinct from the individuals whose activities make up the firm. ${ }^{2}$

We seek to distinguish between an organization's governance structure and its activities. An organization is defined by its governance structure, which we identify as the fundamental rules about who is in, who is out, and who gets what. Organizations arise to pursue opportunities that individuals cannot accomplish independently (Barnard, 1938; Simon, 1947). For an organization to be successful, the benefits of joint production must exceed the costs arising from hazards such as free-riding (actors who do not pull their weight in the expectation that others will do so) and opportunism (Alchian \& Demsetz, 1972; Williamson, 1985). Governance structures attempt to mitigate

\footnotetext{
${ }^{2}$ In corporate law this separation is called "asset partitioning" (Hansmann \& Kraakman, 2000).
}

these hazards by designating certain stakeholders as legitimate holders of decision rights, which we call "enfranchisement," and by specifying how the value created by joint production will be distributed. ${ }^{3}$ This specification, which we discuss in detail below, is important because expectations about claimancy induce stakeholders with critical resources and capabilities to become enfranchised. Stakeholder enfranchisement and claimancy are at the foundation of governance structure.

Once governance structure is established, the regular governance activities of the organization are enabled. Governance activities include events such as meetings of the boards of directors and operations such as the implementation of decision-making protocols and compensation programs. Organizational governance is distinct from organizational strategy, culture, routines, capabilities, and innovation, which take place within the fromework established by the organization's governance structure. Governance is often described as the "rules of the game," within which the game is played. Put differently, governance operates at a higher level of analysis than strategy, organization, and the like (Williamson, 2000).

Enfranchised stakeholders. Enfranchised stakeholders are organizational actors with the de facto ability to influence decision making and, hence, organizational governance. These stakeholders achieve their status as enfranchised because they contribute resources and capabilities that are central to the organization's value creation. In an earlier article, following Blair and Stout (1999), we (Klein, Mahoney, McGahan, \& Pitelis, 2010) identified enfranchised stakeholders as those that coinvest specialized assets, capabilities, and resources through the organization to create value through joint production (see also Hoskisson, Gambeta, Green, \& Li, 2018). In corporations such stakeholders normally include the main suppliers, employees, managers, and the CEO. Customers and the community can also

\footnotetext{
3"Governance is the means by which to infuse order, thereby mitigating conflict and realizing mutual gain" (Williamson, 2005: 3; see also Commons, 1931). In this article changes in the IE lead to new conflicts among stakeholders, and governance adaptation via enfranchisement and/or claimancy rights infuses a new order to realize mutual gain among stakeholders, thereby creating economic value. Below we argue that the enfranchisement of stakeholder groups rests on the conferring of decision rights, which may be both specified and residual. Some stakeholder groups may be only weakly enfranchised-that is, by holding only minor, specified decision rights.
} 
affect decision making through their choices and actions. Enfronchisement describes who is in and who is out of the organization's internal decision-making process and, hence, is a foundational element of governonce structure.

The means of stakeholder enfranchisement may vary. In some instances it may even be legislated by the IE. For example, under Anglo-American corporate law, equity owners of companies are guaranteed enfranchisement via the right to vote for board members and to ratify some executive decisions. Under German law, organized labor is guaranteed board representation and is therefore an enfranchised stakeholder group in every public company. In Norway a certain percentage of board seats is reserved for women. In all three countries the stakeholder groups of equity owners, labor, and women may also be enfranchised in the governance of specific organizations by other means, such as organizational commitments, norms, and informal practices. As we noted in Klein et al. (2010), de facto stakeholder enfranchisement can differ from the de jure arrangements specified by corporate law. The effective rights and responsibilities of enfranchised groups can be determined by custom, by legal practice, and by regulation, as well as by the provisions of corporate law.

Under uncertainty, enfronchisement is particularly important because enfranchised actors have residual rights of control-the rights to make decisions about how to use the firm's resources in conditions not specified by prior agreement (Hart, 1995; Klein et al., 2012). The transaction cost economics literature and property rights economics literature emphasize these residual rights of control but focus on formal, de jure control rights. Over time, stakeholder groups that are not formally enfranchised may become enfranchised de facto following a change in the IE.

The governance of an organization also includes rules on the distribution of jointly created value. We define these rules as the organization's claimancy rights. These identify who gets what through compensation, various payments, and residual rights. All claims on a corporation-not only residual rights-are the subject of governance rules. Examples of claims include employee salories, customer discounts on prices, dividend payments, and partnership claims.

Claimancy rights. Claimancy rights establish which individuals and groups can capture the value created by the organization. Value is created by coinvestment by all stakeholders in shared goods and services. These rights can be fixed (specified) or contingent on firm performance (residual). The right to receive dividends and the right to appropriate capital gains, for example, are essential claimancy rights accruing to equity holders. Debt holders have other claimancy rights, including the right to interest payments and the right of asset appropriation under bankruptcy. Employees and suppliers have claimancy rights over wages, salaries, and factor payments. Other stakeholders may also have claimancy rights, given the legal, political, and social conditions in which the firm operates. Some stakeholders, such as an organization's volunteers and geographic neighbors, may be enfranchised in elements of governance but have no claimancy rights. Claimancy rights matter for governance because they create an incentive for stakeholders to become enfranchised in an organization. It is through claimancy that stakeholders receive a return on the investment of specialized assets, capabilities, and resources in the organization.

Together, enfranchisement and claimancy rights are foundational to an organization's governance structure. Some enfranchised stakeholders contribute more to the organization and, thus, may have more decision-making authority than others, as well as greater claimancy rights. As noted above, those stakeholders with residual rights of control-the rights to make decisions in situations not covered by prior agreement-play a particularly strong role. The size of claims depends, in part, on which claims are fixed, which claims are contingent on earnings, and how claims are ordered in the event of financial distress. In other words, governance structure depends on which individuals have rights and claims-and which rights and claims they have. ${ }^{4}$

Governance structure adaptation may fail if a critical enfranchised stakeholder group

\footnotetext{
${ }^{4}$ It is conventional in the governance literature and finance literature to distinguish residual control rights from residual income rights. This distinction is particularly important for governance adaptation, which relates to structural rather than operational issues. Claimancy rights can be restructured and reallocated by those who have decision rights-that is, by the organization's enfranchised stakeholders. Claimancy, thus, is usually subordinate to enfranchisement, in the sense that enfranchised stakeholders can change claimancy rules. While enfranchisement can also occur through demands for claimancy, these demands may not materialize, allowing us to distinguish the categories for analytical purposes.
} 
threatens to withdraw its cooperation (Hirschman, 1970). For example, labor unions may initiate a strike if management fails to meet their demands for better working conditions (Hill \& Jones, 1992). Governance structure adaptation can attenuate the likelihood of a strike by providing safeguards such as having more insider board members elected by employees of the firm who are making firm-specific investments (Osterloh \& Frey, 2006).

Failure occurs when the joint value created by the organization is too small to compensate each stakeholder sufficiently to ensure continued participation by the stakeholders (Brandenburger \& Nalebuff, 1997). Averting such a threat occurs when, all else being equal, each enfranchised stakeholder has claimancy rights that may not represent the entirety of the stakeholder's added value but that exceed the stakeholder's opportunity costs (Brandenburger \& Stuart, 1996). ${ }^{5}$

In our analysis, governance encompasses a set of claimancy rights established before the organization is set up over value that is realized ofterward. The gap between ex ante claimancy rights and the ex post rules by which claims are distributed reflects, in part, how the organization's governance structure allocates risk among organizational actors. Once governance structures have been established, some stakeholders may seek renegotiation either to create an incentive for future joint investment or to adjust for resolution of risk. The legitimacy of such claims may rest, for example, on differences between stakeholders in sophistication, experience, information, awareness of consequences, capacity for risk, and/or opportunity for coinvestment. ${ }^{6}$

Just as enfranchisement and claimancy are central to governance, changes in enfranchisement and claimancy are central to governance adaptation. Claimancy rights may require renegotiation when a change in the IE leads to the perception by some newly enfranchised

\footnotetext{
${ }^{5}$ An analysis of individuals entering and exiting organizations can be found in the extant organization theory literature under the concept of an "inducements-contribution balance" (Barnard, 1938; Simon, 1947, 1952).

${ }^{6} \mathrm{We}$ distinguish challenges to claimancy rights of the organization's governance structure from negotiations that occur within the structure of a firm's claimancy rights. We focus on governance over claimancy rights, rather than the specific allocation that occurs-changes in the rules of the game, not the play of the game.
}

stakeholders that the existing pattern of rights is inequitable. ${ }^{7}$ Once the firm is in operation and value is realized through the sale of a product or service (Lepak, Smith, \& Taylor, 2007), actual payouts may be different than expected. ${ }^{8}$ Often, the perception of inequity follows a change in the IE that enfranchises new actors. If the perceived inequity is large enough, the existing structure of claimancy rights-along with other aspects of the organization's governance structure-may require an overhaul.

In this article we focus on the adaptation of previously established governance structures that are motivated by changes in the environment surrounding the organization. ${ }^{9}$ Such change can lead some stakeholders to question if the current structure is aligned with their extant or anticipated contribution to firm value and their share of this value. Shifts in the IE can be fully exogenous to the organization and compel its adaptation (although, of course, firms can and do try to influence the IE through lobbying, litigation, public relations, and other forms of nonmarket strategy [Henisz \& Zelner, 2012]). Exogenous shifts in the IE may arise from many sources, including law, government, and culture. One example is a change in customs or ideology, such as when the British vote for $(\mathrm{Br})$ exit from the European Union (EU) led many British-based EU banks to be uncertain about their right to operate in the United Kingdom without a formal subsidiary (as opposed to the branches many use). Another is a change in intellectual property regimes, such as when the World Trade Organization compelled the implementation of patent laws in emerging-market countries where knowledge capital had not previously been privately held. Another is a change in government policies, such as when deregulation designed for a purpose that does not relate

\footnotetext{
${ }^{7} \mathrm{By}$ invoking equity, we are referring not to a specific normative theory of outcomes but, rather, to the (subjective) perceptions among organizational actors concerning the enforcement of prior agreements. In other words, claimancy rights are established when the organization is created based on expectations about value cocreation and the distribution of that value among stakeholders.

${ }^{8}$ This difference happens, for example, if below-average labor productivity or unanticipated outsourcing opportunities lead employees to receive a lower share of cocreated value than expected under employment contracts (Rousseau, 1989).

${ }^{9}$ In other cases governance structures may adapt because the initial governance structure was perceived to be inefficient, ineffective, or unfair and parties only discovered this over time.
} 
to a particular organization's agenda influences the organization nonetheless. ${ }^{10}$

Such shifts in the EE compel not only changes in strategy but also, in many cases, changes in governance structure. For example, Oxley (1999) examined how the IE affects governance structures of interfirm alliances and the governance choice between equity alliances and contractual alliances under differing regimes of intellectual property protection and other national institutional features. Empirically, firms adopt more hierarchical governance modes when intellectual property rights protections are weaker. Therefore, a more complete understanding of governance structure choice requires analysis of the interplay of the IE and the mechanisms of governance.

\section{The Problem of Collective Action}

To be successful in creating value, organizations must resolve collective action problems among critical stakeholders, such as aggregating diverse interests and goals, providing incentives for participation, and coordinating activities. Indeed, the problem of collective action is at the heart of organizational governance, because the purpose of an organization is to jointly deploy the specialized assets, capabilities, and resources of enfranchised stakeholders, each of whom cannot realize value independently. The problem that is resolved by establishing the organization is coordination among enfranchised stakeholders to create joint value.

The institutional economics literature on property rights provides key insights on how resolution may occur in any collective action problem, including the problem of governance adaptation. Organizations such as firms are communities of stakeholders. We submit that the problem of organizational governance is analogous to the problems identified in the literature on institutions and property rights, which is how to achieve agreement among stakeholders on a set of rules that will lead to the joint creation of value.

\footnotetext{
${ }^{10}$ Changes to the IE are not necessarily exogenous to all firms. Efforts to influence legal, regulatory, political, and social conditions may be as important to firms as efforts to influence their competitive and technological environments (Moore, Bell, Filatotchev, \& Rasheed, 2012; Oh \& Oetzel, 2011). For example, firms seek to influence legal, regulatory, and political institutions through lobbying, rent seeking, and other activities (Bonardi, Hillman, \& Keim, 2005; Garud, Hardy, \& Maguire, 2007, Klein et al., 2010).
}

As we aim to show in this article, management scholarship con benefit by importing insights regarding collective action developed in the field of political science.

Ostrom (1990) showed that local communities such as organizations face problems governing "common-pool" resources. Common-pool resources are a subset of "public goods." They are goods that are rivalrous in consumption (one person's use prevents others' use) but nonexcludable (unauthorized users con consume them). Examples from the public domain include fisheries, forests, and irrigation systems. The problems that arise in governing common-pool resources include disputes about pollution; questions over the use of land, water, and other resources; and concerns about how governmental resources will be deployed. Unlike other resources, these connot be managed simply by assigning ownership titles, because common-pool resources belong "to all" in a community; they cannot easily be partitioned into appropriable pieces. Similarly, the enfranchised stakeholders in the organization-an important form of community-contribute specialized resources that create goods that are "public" within the organization, in the sense that they are accessible to the organization's participants.

According to Ostrom (1990), small communities often resolve problems about the use of commonpool resources neither through top-down government control nor through markets and the price mechanism. Rather, close-knit groups rely on complex, layered, and nuanced mechanisms of coordination, collaboration, and communication to identify a path forward. These processes are also characteristic of firms, which rely on internal governance structures to determine how organizational actors will obtain access to valuable internal goods that arise from collective action.

Ostrom (2010) calls these layers of interaction "polycentric" governance. Polycentric systems involve multiple actors and centers of decision making that function with interdependence (Kivleniece \& Quelin, 2012). The approach is costly because it requires intensive coordination (Williamson, 1985). However, Ostrom (1990: 180) has shown that the benefits of polycentric systems outweigh the costs when organizational governance satisfies the following design rules:

- Clear boundaries and memberships: The relevant actors and the resources under consideration are clearly specified. It is well known who gets to decide about what. 
- Congruence between appropriation and provision rules and local conditions: Rules for value appropriation (what we call stakeholder enfranchisement) and provision (what we call claimancy rights) must be aligned with each other and with local economic conditions.

- Peer monitoring: Rules must be self-enforcing through transparency and close monitoring of enfranchised stakeholders by each other.

- Graduated sanctions: Actors who violate organizational standards should face sanctions that are appropriate for the violation and not unnecessarily severe, except in the case of repeat violations.

- Conflict resolution mechanisms: Members of the community should have access to reliable courts, arbitration boards, or internal dispute resolution systems that are perceived as transparent and equitable.

Firm-level examples of common-pool resources include organizational knowledge, brand, corporate culture, reputation, and capabilities. Organizations face multiple challenges in the governance of these resources, the first of which is the foundational problem of attracting stakeholders into enfranchisement. Subsequently, organizations must develop governance structures that determine how jointly produced resources will be deployed, and they must adapt these to changes in the IE that affect the calculus of stakeholder enfranchisement. Ostrom's (1990) design rules constitute principles of effective adaptation. Below we analyze the implications of these design rules for the problem of adaptation in organizational governance. ${ }^{11}$ Before taking on this task, however, we evoke a second set of insights originating in Libecap (1989) on change in the allocation of rights.

Libecap's (1989) analysis of how property rights change in the public domain generates insights that relate to adaptation in private organizational governance. Writing about political governance in local communities, Libecap examined economic hazards that stymie adaptation and described the characteristics of bargaining over access to critical resources. Central elements in Libecap's analysis of community politics are lobbying, distributional conflicts, and asymmetric information, all of which may block changes that

\footnotetext{
${ }^{11}$ Indeed, some of Ostrom's (1990) design rules at the IE level (e.g., monitoring and conflict resolution mechanisms) overlap with Williamson's (1996) mechanisms of governance at the organizational level.
}

would promote overall welfare. Of course, these politics are also characteristic of organizations, especially after operation begins. Libecap was particularly interested in resistance to change when certain private and government actors perceived that they would not gain personally from adaptation, even when the proposed change would benefit the community. We incorporate insights from his analysis to understand why some organizational actors resist change, even when adaptation is compelled by changes in the IE. Organizational stakeholder groups are analogous to the private actors, and organizational executives to governmental actors, in Libecap's analysis.

Libecap's (1989) qualitative studies of change in political governance structures identified factors that distinguish success from failure. The purpose was not to investigate normal change in leadership but, rather, in the rules of governance per se. Two cases stand out. The first was a successful negotiation among miners over the rules governing who could explore where and how jointly identified veins of valuable gold and silver would be allocated. The second was a failed negotiation among landowners over the rules governing how the oil flowing under the land would be extracted. Through comprehensive analysis, Libecap (1989) identified factors that explain whether a group of enfranchised actors can agree on adaptation in governance rules:

- Size of economic gains: The greater the size of the aggregate expected (value creation) gains from the institutional change, the more likely a political agreement can be reached that makes enough influential parties better off so that governance adaptation can proceed.

- Number of coalitions: The greater the number of competing groups with a stake in the new definition of property rights, the more likely distributional conflicts will delay or block change and, thus, the less likely governance adaptation can proceed.

- Coalition heterogeneity: The greater the heterogeneity of the bargaining parties (in terms of production costs, resources, wealth, and political experience), the more difficult it is to form a winning political coalition. This makes adjustments in property rights more difficult and, thus, less likely governance adaptation can proceed.

- Persistence in information asymmetries: The greater the severity of the information asymmetry problems concerning, say, economic valuation, the greater the disputes in bargaining and, thus, the less likely governance adaptation can proceed. 
- Concentration of wealth: The greater the concentration of wealth under the proposed property rights allocation, the greater the likelihood of political opposition and, thus, the less likely that governance adaptation can proceed.

While these ideas about governance adaptation were developed in the context of property rights disputes among communities, we maintain that they apply to organizational governance structures and processes as well. Ostrom's (1990) design principles describe the conditions under which organizations successfully construct governance and can achieve governance adaptation. ${ }^{12}$ Libecap's (1989) criteria describe how stakeholder characteristics influence governance adaptation. Both the Ostrom and Libecap frameworks emphasize who is in, who is out, and who gets what. The key issues surrounding successful governance adaptation in response to IE change are the interests of enfranchised stakeholders (who can affect decision making and, hence, who is in and who is out) and claimancy rights (who gets what parts of the jointly created value). ${ }^{13}$ Figure 1 summarizes these relationships.

As shown in Figure 1, each of Ostrom's design principles and Libecap's adaptation criteria relates to stakeholder enfranchisement and/or claimancy rights. ${ }^{14}$ Ostrom's work (1990) shows that the central challenge of governance is in

\footnotetext{
${ }^{12}$ While some economists focus on Ostrom's (1990) design rules as "equilibrium" outcomes, we emphasize how these rules increase the likelihood of successful governance adaptation (e.g., through graduated sanctions and conflict resolution mechanisms, such as arbitration and mediation procedures).

${ }^{13}$ Libecap (1989) and Ostrom (1990) provided an array of descriptive and prescriptive details, which is organized within our proposed $2 \times 2$ and is intended as a complementary framework to these seminal works. Whetten stated that "sensitivity to the competing virtues of parsimony and comprehensiveness is the hallmark of a good theorist" (1989: 490), and in this article we seek to achieve this balance.

${ }^{14}$ Ostrom described the following design principles as shaping effective governance: "clear boundary and memberships; congruent rules; collective choice arenas; monitoring; graduated sanctions; conflict resolution mechanisms; recognized rights to organize; nested units" (1990: 190). We submit that these elements of design emerge only after establishment of the organization's enfranchised stakeholders and the distribution of value through claimancy rights. Once these fundamental rules of governance arise, then organizational and strategic choices are enabled. When an organization functions well, these choices reflect Ostrom's principles of effective organizational design.
}

specifying which stakeholders are engaged in various processes and in achieving agreement ex ante on claimancy rules that are exercised ex post. The exclusion of some potential stakeholders is essential to the agreement among the remaining enfranchised stakeholders on the claimancy rules. Libecap's work (1989) emphasizes the challenge of sustaining coherent governance arrangements ex post, after the results of the organization's operations resolve-at least in part-the generation of value by the organization, the risks borne by various stakeholders, and the results that occur after the claimancy rules are exercised. As Libecap explained, some stakeholders may seek to participate in governance while others prefer to exit. Libecap's framework also shows that the initial bargaining position of each enfranchised stakeholder typically focuses on improvement from established arrangements. Olson's (1965) analysis demonstrates that stakeholder group size is particularly important to the effective governance of collective goods by attenuating free-riding.

Both Libecap (1989) and Ostrom (1990) emphasized that during the bargaining process stakeholders may recognize that an organization's profile may be fundamentally affected if other stakeholders exit and enter the governance process. Stakeholders who perceive the organization as attractive will try to anticipate how much value the organization will create and how that value will be distributed. Negotiations may reflect the complex positions of various coalitions of stakeholders, each seeking to negotiate prospective claimancy rights and each seeking to threaten competing coalitions with bad outcomes. Thus, the complexity of governance adaptation reflects the broad range of possible outcomes of negotiations over stakeholder enfranchisement and claimancy rights. This stands in stark contrast to the simple conceptualization imported into management from financial economics, in which the salient threat under such circumstances is firm liquidation, with residual cash flows accruing only to shareholders. What Libecap (1989) described is the process by which enfranchised stakeholders renegotiate rather than suffer the extreme consequence of shutting down the firm.

Ostrom (1990) and Libecap (1989) offered extensive insights about the specific resolution of governance adaptation. In this article we do not seek to describe comprehensively how specific 
FIGURE 1

Two Key Drivers of Organizational Governance Adaptation

\begin{tabular}{|c|c|c|}
\hline & Ostrom's design principles & Libecap's adaptation criteria \\
\hline $\begin{array}{c}\text { Stakeholder enfranchisement } \\
\text { (who is in and who is out) }\end{array}$ & $\begin{array}{l}\text { - Clear boundaries and } \\
\text { memberships } \\
\text { - Peer monitoring (who } \\
\text { can impose sanctions) } \\
\text { - Graduated sanctions } \\
\text { (nature of sanctions) }\end{array}$ & $\begin{array}{l}\text { - Number of coalitions } \\
\text { - Coalition heterogeneity }\end{array}$ \\
\hline $\begin{array}{c}\text { Claimancy rights } \\
\text { (who gets what parts of the } \\
\text { jointly created value) }\end{array}$ & $\begin{array}{l}\text { Congruence between } \\
\text { appropriation and } \\
\text { provision rules and } \\
\text { local conditions } \\
\text { - Conflict resolution } \\
\text { mechanisms }\end{array}$ & $\begin{array}{l}\text { - Size of economic gains } \\
\text { - Persistence in } \\
\text { information } \\
\text { asymmetries } \\
\text { - Concentration of } \\
\text { wealth }\end{array}$ \\
\hline
\end{tabular}

adaptations proceed. Rather, we aim to partition the types of adaptation into categories that reflect the foundational elements of Ostrom's and Libecap's insights: stakeholder enfranchisement and claimancy rights. Focusing on these foundational elements of governance produces an integrated and bounded framework that categorizes governance adaptation based on enfranchisement and claimancy rights. These categories illustrate boundary conditions on the types of governance outcomes that may arise, which we call "governance pathways."

\section{A FRAMEWORK FOR GOVERNANCE STRUCTURE ADAPTATION}

How is governance adaptation initiated? Any enfranchised stakeholder perceived as legitimate can initiate the process. We submit that actors' legitimacy tends to reflect the extent and importance of their specific investments of resources, capabilities, time, responsibility, and/or commitment in the organization (Blair \& Stout, 1999). One common impetus for initiating change is uncertainty over the potential impact of shifts in the $\mathrm{EE}$ on the rights and responsibilities of the most enfranchised actors-a key challenge in the organization literature and government literature (Mueller, 1989). For example, increases in global competition, along with higher health care and pension costs for retirees, led GM in the late 2000s to push for substantial reductions in labor costs. The result was a two-day walkout by the United
Automobile Workers (UAW) Union in 2007, the first strike against GM in nearly forty years. Eventually, the UAW membership ratified a landmark 456-page labor agreement with GM, which gave control over retiree health costs to a UAWcontrolled trust fund (Lucas \& Furdek, 2009).

The problem that the UAW and GM initially sought to resolve related to governance over the distribution of value arising from organizational resources created after the company's initial success and, thus, not easily traceable to a particular shareholder group. GM was one of the world's largest and most successful companies, with accrued brand capital, manufacturing expertise, and design capabilities that had emerged over time from the course of the company's operations. However, IE changes in trade policy, along with changes in technology, consumer preferences, and health care costs, left the company vulnerable to foreign competition and led to a struggle among enfranchised stakeholders about how the firm's value could be protected.

This is a general challenge. Because at least some of the common resources that may emerge through organizational action may be impossible to anticipate ex ante, governance activities need continuous adaptation, even if the foundations of governance do not change. At GM, changes in the $\mathrm{EE}$, coupled with stresses arising from governance activities, led to questions about foundational enfranchisement and claimancy rights. Under these circumstances, the previously enfronchised stakeholders initially sought renegotiation because of 
a shared perception that the gains from agreement outweighed the gains from disagreement, in line with Libecap (1989). To be sustainable, the adapted governance structures must enable the creation of sufficient value through joint production to compensate each stakeholder group under the revised terms of governance. Ultimately, GM could not meet this threshold under the renegotiated agreements, and the company entered into bankruptcy on June l, 2009.

Once adaptation in governance begins, a wide range of stakeholder groups may become engaged. This occurs because organizations, like institutional systems, involve the production and use of collective resources, including both common-pool resources and club goods. ${ }^{15} \mathrm{Be}-$ sides the usual problems of value creation and value capture using the firm's other resources, special care must be taken to ensure that shared resources are protected from value dissipation or depletion during the renegotiation. As Libecap (1989) submitted, differences in the information possessed by stakeholders and distributional conflicts result in divergence among bargaining parties, which lowers the likelihood that the existing arrangement will adapt.

As noted above, governance adaptation sometimes occurs when the development of new resources and capabilities in an organization renders the original governance structure ineffective under the prevailing IE. For example, the Partners In Health clinic in Haiti developed a model of unprecedented productivity for treating rural HIV patients based on the engagement of community health workers. This new model, which was celebrated around the world, constituted a significant breakthrough in the delivery of health care to impoverished patients in rural settings. As demands for disseminating this model escalated, Partners In Health sought to invest in its governance structures to support growth (Kidder, 2004).

Governance adaptation is also affected by claimancy rights embedded in the organization's governance structure. Changes in the IE may

\footnotetext{
${ }^{15}$ As noted above, common-pool resources are defined in the public goods literature as goods that are rivalrous in consumption but not excludable, leading to problems of overconsumption. Goods that are excludable but nonrivalrous are called "club goods"; here the canonical problem is underprovision. Examples of firm-level club goods include patents, standards, computer code, and other knowledge resources.
}

embolden claims of inequity in the allocation of the value created by an organization. In general, the less clearly specified an organization's claimancy rules and the more these rules are perceived to be inequitable, the less likely the existing governance structure will resolve disagreements. Similarly, when the resolution of prior uncertainty in the IE leads to a skewed realized distribution of wealth, then stakeholders may seek to renegotiate the rules by which residual claims are distributed. Libecap's (1989) theory of adaptation explains the significance of both stakeholder enfranchisement and claimancy rights to adaptation. On the one hand, shifts in the IE raise the stakes for governance structure adaptation by inviting enfranchisement and legitimizing renegotiation of claimancy rights. On the other hand, institutional change may lead to logjamming by vested interests and/or excessive claims on the organization and, consequently, may raise the specter of organizational failure.

Change in an organization's claimancy rights is different from changes in the distribution that occur as the result of exercise of the rules. For example, at Bank One Corporation, in the year after Jamie Dimon's appointment as CEO in 2000 , the company's senior executives did not receive performance bonuses (Khurana, 2002). This dramatic action was viewed internally as a significant step toward establishing a sense of urgency for the turnaround that Dimon sought to lead, and yet it did not constitute a change in claimancy rights. By contrast, some actions that are viewed within companies as not dramatic at all may constitute changes in claimancy rights. Consider, for example, when a company retires a class of stock or when a school board changes its procedures to allow a panel of teachers to participate in decisions regarding the budget designation of a pool of funds for teacher salaries. Such actions involve changes in claimancy rights that have significant long-term implications for governance structures but relatively little impact in the short run on the actual claims that stakeholders make.

Generally, there are two sets of circumstances in which IE change does not usually lead to governance adaptation. The first is when the anticipated benefits of change for the newly enfranchised groups pushing for change are perceived to be too small to justify the effort. The second is when the required change is perceived to be so great that the organization fails entirely. 
On the first point, governance change is costly. There are explicit costs for negotiating and drafting new legal documents, adding or transferring personnel, and providing audits and related financial reports, as well implicit costs associated with any firm-level change such as overcoming inertia, placing stress on employees, and so on (By, 2005; Fiss \& Zajac, 2006). When these costs are high, the perceived benefits from governance adaptation must be high enough to motivate key stakeholders to bargain. For example, Chrysler Corporation's former CEO, Lee Iacocca, extracted substantial wage and benefit concessions from the UAW to stave off a bankruptcy threat arising from the intense competition that accompanied globalized trade in autos, especially during the 1970s and 1980s. The UAW agreed to the concessions precisely because the threat to the organization's survival was significant. The negotiations led by Iacocca also incorporated new governance arrangements that enfranchised the UAW leader, Douglas Fraser, on the Chrysler board of directors. Thus, in exchange for the concessions, the UAW and the workers that it represented had a voice in the strategy of the firm (Reich, 1984).

There is no guarantee of success in negotiations such as those at Chrysler. For example, in 2012 confectioner Hostess succumbed to bankruptcy and liquidation after failed negotiations to extract wage and benefit concessions from the Bakers Union (Kelley, 2012), despite the threat to the company arising from a cultural shift away from consuming sugary treats.

In many cases, however, governance adaptation proceeds successfully. Below we outline four pathways for governance adoptation and describe the circumstances under which each is likely to occur.

\section{PATHWAYS OF GOVERNANCE ADAPTATION}

When changes in the EE are substantial and unexpected, the organization's initial governance structure may no longer balance competing interests of enfranchised stakeholders. How do organizations adapt to maintain a viable governance structure? The conditions described in the previous section help us to distinguish possible scenarios.

We describe four pathways of governance adaptation by interacting two sets of conditions developed above. Figure 2 illustrates these four cases. The horizontal axis represents the boundary cases on divergence in enfranchised stakeholder interests, while the vertical axis represents the boundary cases on claimancy rights. We call the four pathways of governance adaptation continuity, architectural change, enfranchisement change, and redistribution. Each pathway describes a potential path for governance adaptation; whether an organization will adapt depends on strategy execution, organizational leadership, and the unique features of each situation. On each path some firms may succeed and others may fail. Below we provide some examples of successful and unsuccessful adaptation along each pathway.

\section{Continuity}

When divergence in stakeholder interests is low and claimancy rights are perceived to be equitable, governance structures adapt with continuity (see Figure 2). In this situation a change in the IE requires changes that are perceived as satisfactory (or equitable) by all parties. This, and the fact that the divergence between stakeholder interests is low (i.e., they have largely common interests), implies that governance adaptation can take place without $\alpha$ change in enfranchised stakeholders or claimancy rights.

Continuity may arise even in the face of dramatic shifts in the IE. Consider, for example, the impact of the 9/1l attacks on the governance protocols of New York's money-center banks in ensuring secure and authoritative control over operations. To guard against potential disarray, several banks strengthened and clarified rules of institutional authority and chains of command under various scenarios of disruption. The change in the IE-namely, the $9 / 11$ events-raised the prospect of previously unimaginable threats. By implementing new, contingent rules of governance, the banks adapted with continuity to protect enfranchised stakeholders and to preserve claimancy rules.

Continuity is particularly likely when an organization's established governance structuresincluding claimancy rules-are well suited to emergent resources that are affected by change in the IE. For example, consider the evolution of Facebook. The governance structures established upon the company's initial public offering evolved to address problems and issues that arose during the Arab Spring - a major change in the IE. The evolution occurred with continuity, 
FIGURE 2

Pathways of Governance Adaptation

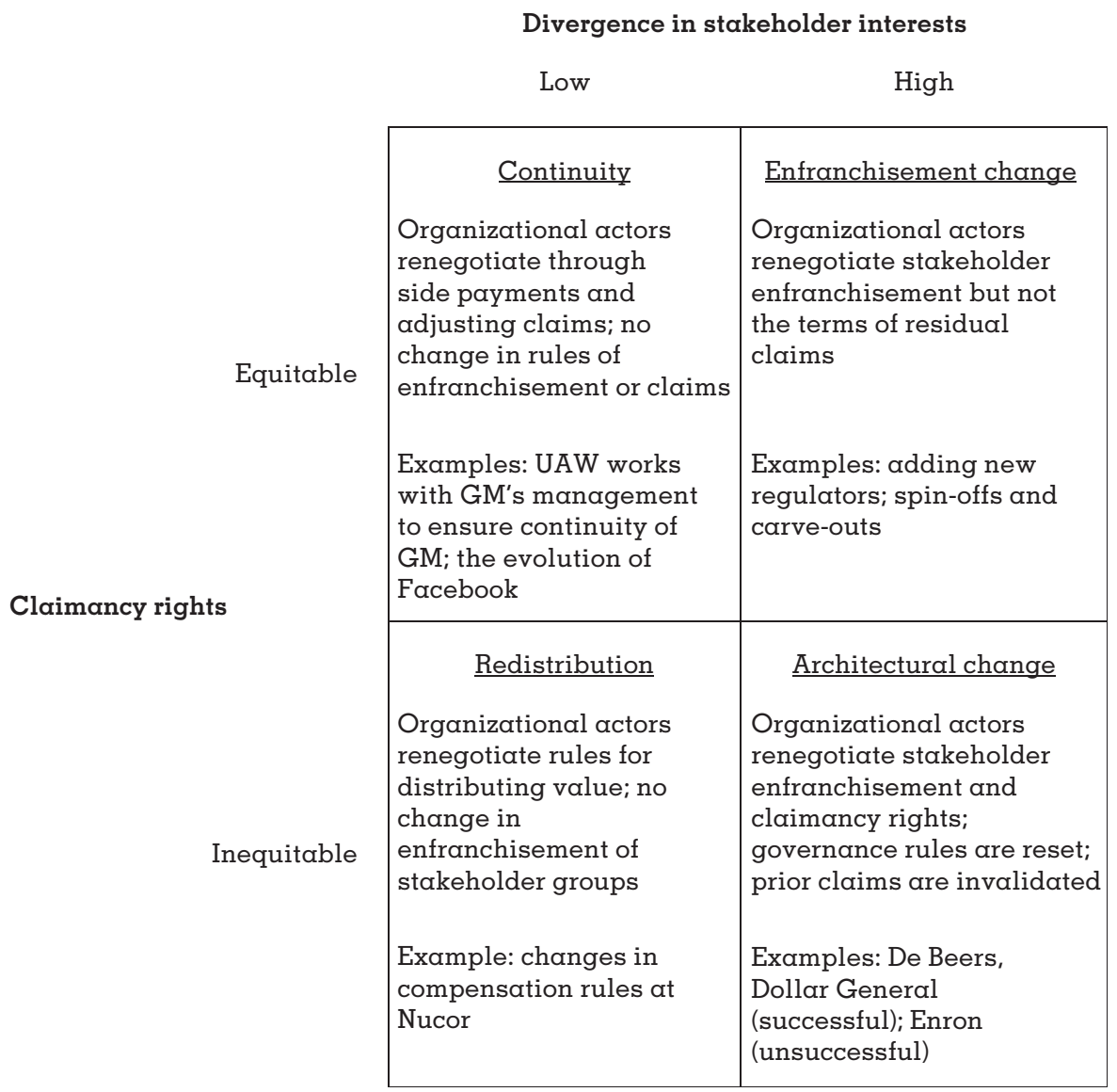

however: Facebook's enfranchised stakeholders clarified the implications of established governance rules without shifting claimancy rights.

In general, continuity tends to arise under the following conditions:

- the initial governance structures accurately anticipate the emergence of common-pool resources:

- the organization creates enough value to generate risk-adjusted returns on investment satisfactory to each enfranchised stakeholder with claimancy rights;

- the resolution of uncertainties regarding value creation does not create disproportionate burdens on particular stakeholders; and

- there are no major shocks or challenges to the legitimacy of the value created by the enterprise.

\section{Architectural Change}

An extreme alternative pathway arises when an organization's governance structures change architecturally in the face of shifts in the IE. Consider, for example, the Tōhoku earthquake and tsunami of 2011, which caused a disaster at the Fukushima Daiichi Nuclear Power Plant owned by the Tokyo Electric Power Company (TEPCO). The prospect of liability claims, fueled by expectations that the courts would find the company negligent, led TEPCO to seek an infusion of cash from the Japanese government in exchange for partial nationalization and the inclusion of government officials on the top management team and board (Obe, 2012). The transition involved a tragically motivated recognition of the interests of all Japanese people in the company's operations-as well as a shift in claimancy rules to reflect the devastating impact of the disaster on the citizens of Fukushima Prefecture. The disaster led to a shift in public opinion about who bears responsibility for nuclear safety, which constituted a change in the IE that led to an important change in governance. 
Here we suggest that when divergence of stakeholder interests is high and when the standing specification of claimancy rights is perceived as inequitable, a comprehensive and systemic adaptation will occur. We refer to this adaptation as architectural change (see Figure 2). Architectural changes occur when the established governance structure is so significantly inadequate to respond to changes in the IE that the organization must be reconstituted differently. When architectural change succeeds, the organization's assets, capabilities, activities, and routines become governed under new rules designed to conform to the new IE. In other cases the need for architectural change may result in the failure of the organization entirely.

This form of change is difficult to accomplish because it requires redesigning many elements of a system simultaneously (Scott, 1987; Simon, 1962). The inability to adapt may lead to entirely abandoning some elements of governance as they fail in the face of unsuccessful negotiations between groups of stakeholders with divergent interests, and as the result of unsuccessful resolution of rivalry over claimancy rights. What emerges is a governance structure that may enfranchise only a subgroup of the initial stakeholders. Such a situation arises under the following kinds of conditions:

- the initial structures of governance are constructed under considerable uncertainty about forthcoming shifts in the IE, which may lead to claims by initially disenfranchised stakeholder groups;

- the value created by the organization is only marginally sufficient to compensate enfranchised stakeholders with claimancy rights above what they would receive if they were to pursue outside options;

- the common-pool resources that arise have value to only a small group of stakeholders;

- disenfranchised stakeholders make strong, legitimate claims on the activities of the organization; and

- the resolution of uncertainties regarding value creation does not create disproportionate burdens on particular stakeholders.

The De Beers case discussed above represents a case of successful architectural adaptation. The existing rules of stakeholder enfranchisementwhich largely excluded most of the local population from equity ownership, senior management positions, and exercises of decision authority-were renegotiated. The old rules of distribution-which were perceived to be highly inequitable-were restructured to give a greater share of firm value to nonwhite stakeholders. The IE change in this case was the end of the apartheid system. The postapartheid Black Economic Empowerment act required mining companies such as De Beers to have 15 percent black ownership by 2005. The result was a radically restructured De Beers, in which established resources and capabilities were deployed under a new governance structure.

In some cases successful architectural change is initiated from within the organization, such as when a company seeks to be restructured or acquired for access to the governance structure of the new parent or combined firm. Consider, for example, a leveraged buyout by management of a company, such as occurred at Dollar General in 2007 (Roe, 2013). Former investors willingly became disenfranchised through the sale of their shares to management. This transfer of ownership also changes the rules of claimancy by providing those managers who buy with residual rights and with enhanced authority to change compensation systems. At Dollar General such an architectural change in governance occurred because of negotiations between enfranchised stakeholders, rather than fiat from an external authority.

In other cases, however, architectural change is so daunting that the result is organizational collapse, despite attempts by external authorities to mitigate conflicts. Consider, for example, the effect of partial deregulation in the trading of U.S. energy contracts and the infamous failure of Enron. Because Enron's governance structures were not adapted to reflect the interests of previously disenfranchised groups of stakeholders-in particular, the citizens of California-the company's traders engaged in practices that led to energy shortages and blackouts there (McLean \& Elkind, 2003). Negotiations over rules of claimancy on the company failed, in part, because profits from trading had been disbursed in bonus compensation packages to senior employees and traders, thus leaving the company with insufficient funds to compensate stakeholders with claims that were eventually adjudicated in the IE as legitimate.

Libecap (1989) considered two key cases of successful and unsuccessful architectural change. The first was the carefully studied case of mineral rights in the American West. The landowners believed they owned property under which these valuable minerals were buried, but none of them knew precisely where the minerals lay. To avoid 
duplicative exploratory and extractive digging, and to avoid flooding the market with minerals, landowners cooperated to manage exploration, extraction, and sale. In other words, they renegotiated their stakeholder rights from an individual to shared model, while agreeing to distribute claims evenly across landholders. Continuous improvements in rules governing the underground boundaries of mineral veins were established to protect property holdings (Libecap 1978). The continuity in governance rules arose because each of the landowners realized that the loss of some individual rights through cooperation would yield a greater return than from uncoordinated competition.

Architectural change in this case was successful for the reasons described by Libecap's (1989) five factors. First, the expected aggregate gains from establishing secure private property rights were large (Bromley, 1989). Second, the number of contracting parties among landowners was typically small-in the range of twenty to thirty individuals (Libecap, 1989). Third, the groups were relatively homogeneous with respect to experiences and expectations regarding legal institutions (Hallagorn, 1978). Fourth, asymmetric information problems were low-that is, information was similarly distributed among the contracting parties (Olson, 1982). Fifth, most of the contracting parties expected a share in the large, aggregate economic gains from establishing these property rights (Umbeck, 1977). Therefore, despite the potential private gains that each londowner might obtain by defecting from the group, the gains to the group that accrued from the coordination of mining effort were so great that each miner cooperated.

Libecap's (1989) second IE-level example concerned an architectural change that was too difficult and where existing arrangements fell apart. This problem arose among landowners seeking to extract oil from a newly discovered common oil field. In this example, landowners who had settled in particular areas received the unanticipated news of valuable, extractable oil under their land. Land over subsurface oil reservoirs in the United States often has multiple owners. The oil is migratory and can move within a reservoir, so a landowner drilling on their own land can extract oil that was under a neighbor's land (McDonald, 1971). In Texas, landowners may drill a well on their land and drain oil and gas from neighbors without liability (Lueck, 1995), since property rights to oil and gas are assigned upon extraction. However, by collaborating, neighbors with land over the common oil field can achieve greater returns than by competing. This arrangement, called "unitization," occurs when a single drill is constructed to extract oil at a rate that is negotiated among the neighbors; the profits are then split in proportion to each landholder's share. Through such collaboration the neighbors not only avoid the duplicative and technical costs of multiple drills (Smith, 1987) but also do not compete to drive down the local price of extracted oil, thus raising joint profits (Kim \& Mahoney, 2002).

The economic gains from oil field unitization have been understood since the first oil discovery in the United States-in Pennsylvania in 1859. Yet we observe a surprisingly low rate of oil field unitization, particularly in Texas (Bain, 1947; Weaver, 1986). To understand why, consider the contractual impediments to achieving oil field unitization. First, gains from unitization are especially low when many parties have large holdings (e.g., sometimes with hundreds of owners; Libecap \& Smith, 2001). Second, contracting parties tend to be heterogeneous (e.g., some parties primarily own oil and others gas). Third, uncertainty and asymmetric information lead to diverse valuations of each contracting party's shares. Because each contracting party undertakes calculations by doing tests based on its own land, with a limited number of observations as well as bores, it is not surprising that calculations vary across different parties (Libecop \& Wiggins, 1984).

The success or failure of architectural change depends largely on the strength of interest groups (Eggertsson, 1990; Olson, 1982), and the problems identified in the "rent-seeking" literature (Krueger, 1974; Murphy, Shleifer, \& Vishny, 1993) provide key insights for explaining why an inefficient outcome persists. ${ }^{16}$ Demsetz's (1967)

\footnotetext{
${ }^{16}$ Although beyond the scope of this article, there are important sociological factors influencing interest group formation, such as the development and elaboration of collective action frames as meaning construction, problem identification, frame diffusion, and collective identity, as well as contextual constraints and facilitation (e.g., political opportunity structure and cultural constraints and opportunities; Benford \& Snow, 2000). Building on this research, Henisz and Zelner (2005) emphasized the impact of cognitive limitations by various stakeholders and varying normative pressures, institutional constraints, and social influences on effective change as an ongoing process at both the level of governance structures and institutional arrangements at the IE level.
} 
optimistic view of the evolution of property rights toward efficiency implicitly posits that governments will typically act to minimize transaction costs. In the case of oil field unitization in the United States, this premise did not hold, and some government decision makers had economic incentives to maintain the status quo (Libecap, 1989). Further, political processes in contracting for property rights also are prone to free-riding problems in group decision-making processes (Olson, 1965; Ostrom, 1990).

\section{Enfranchisement Change}

Between the two extremes of continuity and architectural change are two pathways of governance adaptation that have been underexplored in prior literature: stakeholder enfranchisement change and redistribution. Enfranchisement change occurs when divergence in stakeholder interests is high, yet, post change, claimancy rights are seen as equitable (see Figure 2). In this case the key to adaptation is to let new stakeholders in and/or remove other stakeholders. Enfranchisement change reflects an adaptation in the groups of stakeholders with rights in on organization's governance structure, including decision rules, managerial rights, and reporting procedures. Rules of claimancy are not adjusted, but groups of stakeholders are either excluded or included in the organization's governance. Such enfranchisement change may also involve implementation of eligibility for claimancy but not change the rules by which claimancy occurs. In some cases enfranchisement may occur without providing any claimancy rights, such as when a company creates a program for volunteers or when it seeks the advice of community members in governance decisions. When organizations create noncompensatory partnership arrangements and memos of understanding that influence governance, they are on a pathway of enfranchisement change.

Enfranchisement change is common. Whenever a publicly traded company creates a partnership agreement or a merger that gives the target entity a voice in governance, then enfranchisement change occurs. It is important to note that this pathway excludes cases where claimancy rights also change. For example, enfranchisement change occurs when a small, venture-backed entrepreneurial organization establishes a new partnership agreement that does not change or dilute the claimancy rights of the management team or the venture backers. By contrast, architectural change occurs when the same organization's partnership agreement influences the distribution agreements.

Enfranchisement change may be subtle. The threshold criterion for its occurrence is change in the ownership and control rights that shape the organization's core activities. Science-based pharmaceutical companies have created advisory boords that reflect the health requirements, medical infrastructure, and legal positions of jurisdictions that may seek access to medicines. Open-source software development companies create panels to represent the interests of potential customers and to advise participants on technical and legal issues regarding the commercialization of applications built on the general purpose technology. Each of these examples represents change designed to enfranchise stakeholder groups without a wholesale reconstitution of the organization's claimancy rights.

In some instances organizations adapt governonce structures by excluding previously enfranchised stakeholder groups. Spin-outs may occur as stakeholder groups pursue outside governance options, such as when John Warnock and Chuck Geschke left the Xerox Corporation to form Adobe after Xerox declined to invest in the technology that subsequently became PostScript (Chesbrough \& Rosenbloom, 2002). In some cases stakeholder groups are forced out of companies; hostile takeover bids and leveraged buyouts frequently lead to the departure of large groups of managers under restructuring actions designed to make companies more efficient (Krug \& Hegarty, 1997). Less contentiousness adaptation may also occur as groups of stakeholders are enfranchised in management decisions. These examples represent sometimes dramatically different decision-making and managerial systems, but the initial organizational governance structure retains its identity.

Conditions that tend to favor stakeholder enfranchisement change include the following:

- the operations of the organization under the initial governance structure reveal the legitimate claims of previously disenfranchised stakeholders;

- a group of enfranchised stakeholders seeks exit from the responsibilities of governance because of revealed outside alternatives that 
are more economically attractive than continued engagement;

- internal disagreements between stakeholder groups about resource allocation decisions raise the costs of collaboration, leading some groups to seek exit; and

- the emergence of organizational resources imposes costs on stakeholders, leading to requirements for adjustment.

\section{Redistribution}

The fourth pathway involves changing the terms by which groups of stakeholders claim value from the organization. Such changes are called "redistributive" because they are zero sum: when one stakeholder group, such as employees, wins the right to a greater claim on an organization's value than it previously had, then, de facto, some other stakeholder group loses the claim. Redistribution occurs when divergence in stakeholder interests is low yet the rules by which residual claims are distributed are perceived to be inequitable (see Figure 2).

Redistribution may occur when those already enfranchised within an organization's governance model seek to avert a disruption by voluntarily giving up some of their rights. The idea that those in power would voluntarily waive some of their property rights to preserve or even increase their wealth is well established (Blair \& Stout, 1999; Schelling, 1960). For example, Alexy and Reitzig (2013) showed empirically that environmental shocks can be triggers for an innovative firm to waive its exclusion rights for the purpose of coordinating among several participants, which can enable them to jointly design industry-regulating institutions to facilitate economic value copture. Thus, gaining (de facto) control over a resource may come about by giving (formal) control away.

Examples of changes in claimancy rights are also relatively common. Consider the minimill steel business of Nucor, which gives substantial autonomy to its operating divisions (Ghemawat, 1995). Originally, the compensation of Nucor's executives was tied to the performance of the individual divisions. This arrangement worked well when the prevailing technology for operating each division was the blast furnace, since the geographic footprints of the divisions were different. However, the emergence of minimill technology - $\alpha$ shift in the technological part of the EE-put Nucor on a redistribution pathway. Because minimills allowed each Nucor division to compete fiercely in geographic territories that had been dominated previously by other Nucor divisions, the company was thrown into a governance crisis. To resolve the problem, the company adapted its claimancy rules so that executive pay would reflect overall corporate performance, rather than divisional performance. This change in claimancy rights created a powerful incentive for cooperation among the divisional executives. Nucor's governance structure was adapted to allow greater claimancy rights within the divisions on economic value created at the level of the corporation. Thus, divisional managers' compensation was based on corporate return on equity, which aligned the incentives of business division-level strategy and corporate-level strategy (Ghemawat, 1995).

Conditions under which redistribution tends to arise include the following:

- the resolution of initial uncertainties about the creation of value reveals that a stakeholder group's costs or benefits are disproportionately out of alignment with those anticipated;

- the outside opportunities of one or more stakeholder groups change in relationship to those of other stakeholder groups; and

- the resources held by the organization, and/or the opportunities it faces, require disproportionate investment by one or more enfranchised stakeholder groups.

\section{DISCUSSION AND CONCLUSIONS}

Governance structures must adapt to the IE if an organization is to survive. This is especially true when the changes arise in the firm's IE. In this article we have provided a general framework for governance adaptation describing how parties in an organization attempt to resolve conflicts over the value cocreated from shared resources. Our framework builds on the institutional economics literature on collective goods because negotiating organizational governance structures is a problem of aligning stakeholder interests for joint production - the same problem studied by Ostrom and Libecap. Ostrom (1990) described conditions under which parties can resolve conflicts over shared resources when parties have differing goals, interests, bargaining strength, and beliefs about what they deserve. Libecap (1989) showed how characteristics of the bargaining parties and the economic value of the underlying resources affect the ability to arrive at different solutions. 
Conflicts over shared resources boil down to disagreements about who is in and who is out, which we call enfranchisement, and who gets what, which we call claimancy. As we discussed above, enfranchisement and claimancy are similar to the organizational economics and corporate finance concepts of decision rights and cash flow rights, respectively, but they go beyond efficiency to include considerations of distribution and fairness. We described four pathways of governance adaptation determined by the divergence of interest among enfranchised stakeholders and the degree to which claims on firm value are perceived to be equitable.

The first contribution emerging from our anclysis is the two parallel arguments regarding drivers of governance adaptation at the level of the organization. Our first argument emphasizes divergence in stakeholder interests, while the second focuses on claimancy rights. By distinguishing between the foundations of governance-namely, stakeholder enfranchisement and claimancy-and governance activities, we seek to clarify and simplify the canonical problem of governance adaptation. Each stakeholder group considers the impact of a change in the EE on the organization's standing governance structure. A critical point in the development of our theory is that the transition by organizations in confronting increasingly challenging collective action problems creates conditions that tend to enfranchise new stakeholders and to impact claimancy rights.

We next specified four pathways of governance adaptation-continuity, architectural change, enfranchisement change, and redistribution-that reflect boundary conditions established by our arguments. These pathways provide a taxonomy for researchers seeking to understand organizational change; they may also be useful to practitioners seeking to address the implications of changes in the EE for governance.

Our theory also demonstrates several ways the EE-the IE in particular-and the organization interact. For instance, organizational governance structures reflect the legal, political, social, and cultural rules established by the IE, thus providing the backdrop against which organizational governance operates. Stakeholders may revert formally or informally to the IE to adjudicate claims on organizational governance.

Finally, the process of governance adaptation in organizations is analogous to institutional (property rights) arrangement adaptation at the level of the IE. Consequently, we identify a substantial overlap of Williamson's (1985) mechanisms of governance at the organization level and Ostrom's (1990) institutional design principles at the institutional level as means of attenuating these collective-action problems (e.g., monitoring and dispute resolution mechanisms). However, as noted, both organizational and institutional adaptation-when architectural change is required-are difficult.

Our analysis points to several opportunities for further research. First, the microprocess of endogenously driven governance structure change needs greater attention. Consider Williamson's (1985) concept of the "fundamental transformation," which describes how economic relationships change over time as relationshipspecific investments are made. This logic applies to shared resources and collective action. Agreements to share common-pool resources may initially be effective but may deteriorate as the specific investments weaken the bargaining positions of parties, leading to costly renegotiation. The fundamental transformation at the governance level has a parallel application at the institutional level-for example, as in Vernon's (1977) "obsolescing bargain model" (see Bucheli \& Kim, 2015, and Nygaard \& Dahlstrom, 1992). Insights derived from these and especially sociological theories of process change would advance understanding of governance adaptation.

Second, an important opportunity arises in understanding the capabilities required both for effective governance and effective governance adaptation. The management literature emphasizes that organizational capabilities to write and enforce effective contracts develop over time, as contracting parties experiment and learn (Argyres \& Mayer, 2007; Mayer \& Argyres, 2004). Thus, even after effective governance mechanisms for sharing common-pool resources have emerged, there is the potential for ex post opportunism if the exchange parties subsequently make relationship-specific investments. In other words, while we focus mainly on applying insights from the institutional (property rights) arrangement literature to the organizational governance structure literature, the institutional governance literature can also benefit from considering core concepts from organization theory, beyond our modified variant of contingency theory.

Third, additional research is required on the implications for organizational governance 
structure adaptation of relationships between organizations in the IE. Examining interactions among and between organizational governance structures would illuminate the social and political relevance of organizational research (Klein, Mahoney, McGahan, \& Pitelis, 2013) and would clarify how norms, rules, expectations, and risk tolerance in the IE change. Explicating these interactions more systematically can provide guidance for managers operating across institutional contexts and within dynamic competitive landscapes. Not only will examination of this interplay inspire substantial empirical testing but it will also generate multilevel theory development to explore parallels between organizational governance mechanisms and institutional design principles that benefit both management and global business research. ${ }^{17}$

Fourth, there is scope for clarifying the relationships between stakeholders within the IE and organizational governance structure change using a formal model. This approach can also enable us to distinguish cases in which effective rules for governing shared resources emerge endogenously (e.g., by a firm's strategic behaviors, such as lobbying to change the IE [Hillman \& Hitt, 1999; Holburn \& Vanden Bergh, 2008]) from cases in which a given set of smooth governance structure rules must adapt to shifts in the IE (which has been our focus in this article). A formal model would also shed light on the speed with which such adaptations take place.

Fifth, our illustrations suggest important questions that must be addressed empirically. Largesample datasets that reflect governonce structure change would yield important insights about the design principles that govern interaction. There may be contexts, such as public-private procurement arrangements (Quelin, Cabral, Lazzarini, \& Kivleniece, 2014), where detailed information about sharing rules can be extracted from survey data. Additional qualitative assessments are certainly warronted. Over the long run, a panel dataset that includes information about both the IE and organizational governance would yield important insights about governance structure change and its consequence.

\footnotetext{
${ }^{17}$ The common-pool resource institutional research literature often neglects some of Williamson's (1996) governance mechanisms, such as mutual commitment, while the governance structure literature often neglects some of Ostrom's (1990) institutional design principles, such as graduated sanctions and peer monitoring. Thus, a synthesis of design solutions is a contribution to both theory and practice.
}

Sixth, an analysis of the expected influence of $\mathbb{E}$ change on orgonizational governance structures through its impact on organizational actors and dynomics con help monagers anticipate and mold chonge at the IE level, as well as the fit between the $\mathbb{E}$ level and organizational governance structures. This modified variont of contingency theory con thus aid managerial practice to help foster efficient adoptation.

Finally, additional research is required on fairness, equity, justice, and legitimacy (Meyer, Boli, Thomas, \& Ramirez, 1997; Oliver, 1992) as outcomes of organizational governance adaptation. These important criteria for the resolution of intercoalitional conflict must be considered as institutional innovations and organizational governance structure chonges are implemented. This is particularly relevant for complex interactions among public and private actors on issues such as health care reform and environmental policy. As Kinzig et al. (2013) have noted, solving such "wicked problems" involves not only changes in personal and social norms but also specific governance mechanisms (e.g., regulations and financial interventions) that interact with norms in complex and hard-to-predict ways. In other words, adaptations at different institutional levels work together, not independently. For management scholarship this interdependence suggests that closer attention to mechanisms and processes of institutional change may yield a better understanding of organizational governance.

While we have focused primarily on applying insights from the institutional governance literature to inform management research and practice, the analysis suggests that careful consideration of organizational governance-as well as of strategy and entrepreneurship-con deepen our understanding of institutional problems. Just as organizational stakeholders choose whether to initiate, support, or resist organizational change based partly on their beliefs about how much value will be created and how much they can appropriate, so, too, does social and political change depend on the beliefs of key participants about social and political value creation and value capture. Further exploration is needed to evaluate whether and when such coadaptation fosters efficient and effective governance of the IE, in contrast to the capture of the IE by organizational actors who seek to exclude particular stakeholders.

The results of the modified variont of contingency theory developed here also suggest that change in the IE and the adaptive responses in organizational governance structures that result may create new 
opportunities for deploying emergent organizational resources for value creation. Ultimately, the realization of a society's most important economic opportunities to innovate depends on the alignment between the rules and norms that prevail in the IE and organizational governance structures.

\section{REFERENCES}

Alchian, A. A., \& Demsetz, H. 1972. Production, information costs, and economic organization. American Economic Review, 62: 777-795.

Alexy, O., \& Reitzig, M. 2013. Private-collective innovation, competition, and firms' counterintuitive appropriation strategies. Research Policy, 42: 895-913.

Argyres, N., \& Mayer, K. J. 2007. Contract design as a firm capability: An integration of learning and transaction cost perspectives. Academy of Management Review, 32: 1060-1077.

Bain, J. S. 1947. The economics of the Pacific Coast petroleum industry: Public policy toward competition and price. Berkeley: University of California Press.

Barnard, C. I. 1938. The functions of the executive. Cambridge, MA: Harvard University Press.

Benford, R. D., \& Snow, D. A. 2000. Framing processes and social movements: An overview and assessment. Annual Review of Sociology, 26: 611-639.

Blair, M. M., \& Stout, L. A. 1999. A team production theory of corporate law. Virginia Law Review, 85: 247-328.

Bonardi, J.-P., Hillman, A. J., \& Keim, G. D. 2005. The attractiveness of political markets. Academy of Management Review, 30: 397-413.

Brandenburger, A. M., \& Nalebuff, B. J. 1997. Co-opetition: 1. A revolutionary mindset that combines competition and cooperation. 2. The game theory strategy that's changing the game of business. New York: Doubleday.

Brandenburger, A. M., \& Stuart, H. W. 1996. Value-based business strategy. Journal of Economics and Management Strategy, 5: 5-24.

Bromley, D. W. 1989. Institutional change and economic efficiency. Journal of Economic Issues, 23: 735-759.

Bucheli, M., \& Kim, M. 2015. Attacked from both sides: A dynamic model of multinational corporations' strategies for protection of their property rights. Global Strategy Journal, 5: 1-26.

By, R. T. 2005. Organizational change management: A critical review. Journal of Change Management, 5: 369-380.

Chandler, A. D. 1962. Strategy and structure: Chapters in the history of the American enterprise. Cambridge, MA: MIT Press.

Chesbrough, H., \& Rosenbloom, R. S. 2002. The role of the business model in capturing value from innovation: Evidence from Xerox Corporation's technology spin-off companies. Industrial and Corporate Change, 11: 529-555.

Commons, J. R. 1931. Institutional economics. American Economic Review, 21: 648-657.

Cyert, R. M., \& March, J. G. 1963. A behavioral theory of the firm. Englewood Cliffs, NJ: Prentice-Hall.
Demsetz, H. 1967. Towards a theory of property rights. American Economic Review, 57: 347-359.

Eggertsson, T. 1990. Economic behavior and institutions. Cambridge: Cambridge University Press.

Fiss, P. C., \& Zajac, E. J. 2006. The symbolic management of strategic change: Sensegiving via framing and decoupling. Academy of Management Journal, 49: 1173-1193.

Foss, N. J., \& Mankhe, V. (Eds.). 2002. Competence, governance, and entrepreneurship: Advances in economic strategy research. New York: Oxford University Press.

Galbraith, J. R. 1973. Designing complex organizations. Reading, MA: Addison-Wesley.

Garud, R., Hardy, C., \& Maguire, S. 2007. Institutional entrepreneurship as embedded agency. Organization Studies, 28: 957-969.

Ghemawat, P. 1995. Competitive advantage and internal organization: Nucor revisited. Journal of Economics \& Management Strategy, 3: 685-717.

Grossman, S. J., \& Hart, O. D. 1986. The costs and benefits of ownership: A theory of vertical and lateral integration. Journal of Political Economy, 94: 691-719.

Hallagan, W. S. 1978. Share contracting for California gold. Explorations in Economic History, 15: 196-210.

Hansmann, H. 2006. Corporation and contract. American Law and Economics Review, 8: 1-19.

Hansmann, H., \& Kraakman, R. 2000. Organizational low as asset partitioning. European Economic Review, 44: 807-817.

Hart, O. 1995. Firms, contracts, and financial structure. Oxford: Clarendon Press.

Hayek, F. 1945. The use of knowledge in society. American Economic Review, 35: 519-530.

Hendry, K., \& Kiel, G. C. 2004. The role of the board in firm strategy: Integrating agency and organizational control perspectives. Corporate Governance: An International Review, 12: 500-520.

Henisz, W. J. 2000. The institutional environment for economic growth. Economics \& Politics, 12: 1-31.

Henisz, W. J., \& Zelner, B. A. 2005. Legitimacy, interest group pressures, and change in emergent institutions: The case of foreign investors and host country governments. Academy of Management Review, 30: 361-382.

Henisz, W. J., \& Zelner, B. A. 2012. Strategy and competition in the market and nonmarket arenas. Academy of Management Perspectives, 26(3): 40-51.

Hill, C. W., \& Jones, T. M. 1992. Stakeholder-agency theory. Journal of Management Studies, 29: 131-154.

Hillman, A. J., \& Hitt, M. A. 1999. Corporate political strategy formulation: A model of approach, participation, and strategy decisions. Academy of Management Review, 24: 825-842.

Hirschman, A. O. 1970. Exit, voice, and loyalty: Responses to decline in firms, organizations, and states. Cambridge, MA: Harvard University Press.

Holburn, G. L., \& Vonden Bergh, R. G. 2008. Making friends in hostile environments: Political strategy in regulated industries. Academy of Management Review, 33: 521-540. 
Hoskisson, R. E., Gambeta, E., Green, C. D., \& Li, T. X. 2018. Is my firm-specific investment protected? Overcoming the stakeholder investment dilemma in the resource-based view. Academy of Management Review, 43: 284-306.

Kelley, M. B. 2012. How workers and management both caused the demise of Hostess. Business Insider, November 16: http:// www.businessinsider.com/how-workers-and-managementboth-caused-the-fall-of-hostess-2012-11.

Khurana, R. 2002. The curse of the superstar CEO. Harvard Business Review, 80(9): 60-67.

Kidder, T. 2004. Mountains beyond mountains. New York: Random House.

Kim, J., \& Mahoney, J. T. 2002. Resource-based and property rights perspectives on value creation: The case of oil field unitization. Managerial and Decision Economics, 23: 225-245.

Kinzig, A. P., Ehrlich, P. R., Alston, L. J., Arrow, K., Barrett, S., Buchmon, T. G., Daily, G. C., Levin, B., Levin, S., Oppenheimer, M., Ostrom, E., \& Saari, D. 2013. Social norms and global environmental challenges: The complex interaction of behariors, values, and policy. BioScience, 63: 164-175.

Kivleniece, I., \& Quelin, B. V. 2012. Creating and capturing value in public-private ties: A private actor's perspective. Academy of Management Review, 37: 272-299.

Klein, P. G., Mahoney, J. T., McGahan, A. M., \& Pitelis, C. N. 2010. Toward a theory of public entrepreneurship. European Management Review, 7: 1-15.

Klein, P. G., Mahoney, J. T., McGahan, A. M., \& Pitelis, C. N. 2012. Who is in charge? Value co-creation and a property rights perspective on stakeholder value. Strategic Organization, 10: 304-315.

Klein, P. G., Mahoney, J. T., McGahan, A. M., \& Pitelis, C. N. 2013. Capabilities and strategic entrepreneurship in public organizations. Strategic Entrepreneurship Journal, 7: 65-86.

Krueger, A. O. 1974. The political economy of the rent-seeking society. American Economic Review, 64: 291-303.

Krug, J. A., \& Hegarty, W. H. 1997. Post-acquisition turnover among US top management teams: An analysis of the effects of foreign vs. domestic acquisitions of US targets. Strategic Management Journal, 18: 667-675.

Lawrence, P. R., \& Lorsch, J. W. 1967. Organization and environment: Managing differentiation and integration. Boston: Division of Research, Graduate School of Business Administration, Harvard University.

Lepak, D. P., Smith, K. G., \& Taylor, M. S. 2007. Value creation and value capture: A multilevel perspective. Academy of Management Review, 32: 180-194.

Libecap, G. D. 1978. The evolution of private mineral rights: Nevada's Comstock Lode. New York: Arno Press.

Libecap, G. D. 1989. Contracting for property rights. Cambridge: Cambridge University Press.

Libecap, G. D., \& Smith, J. L. 2001. Regulatory remedies to the common pool: The limits to oil field unitization. Energy Journal, 22: 1-26.

Libecap, G. D., \& Wiggins, S. N. 1984. Contractual responses to the common pool: Prorationing of crude oil production. American Economic Review, 74: 87-98.
Lucas, J. J., \& Furdek, J. M. 2009. The labor agreements between UAW and the Big Three automakers: Good economics or bad economics? Journal of Business \& Economics Research, 7: 41-46.

Lueck, D. 1995. The rule of first possession and the design of the law. Journal of Law and Economics, 38: 393-436.

Mahoney, J. T. 2005. Economic foundations of strategy. Thousand Oaks, CA: Sage.

Mayer, K. J., \& Argyres, N. S. 2004. Learning to contract: Evidence from the personal computer industry. Organization Science, 15: 394-410.

McDonald, S. L. 1971. Petroleum conservation in the United States: An economic analysis. Baltimore: Resources for the Future.

McLean, B., \& Elkind, P. 2003. The smartest guys in the room: The amazing rise and scandalous fall of Enron. New York: Penguin.

Meyer, J. W., Boli, J., Thomas, G. M., \& Ramirez, F. O. 1997. World society and the nation state. American Journal of Sociology, 103: 144-181.

Moore, C. B., Bell, R. G., Filatotchev, I., \& Rasheed, A. A. 2012. Foreign IPO capital market choice: Understanding the institutional fit of corporate governance. Strategic Management Journal, 33: 914-937.

Mueller, D. C. 1989. Public choice. Cambridge: Cambridge University Press.

Murphy, P. C., Shleifer, A., \& Vishny, R. W. 1993. Why is rentseeking so costly to growth? American Economic Review, 83: 409-414.

North, D. C. 1990. Institutions, institutional change, and economic performance. Cambridge: Cambridge University Press.

Nygaard, A., \& Dahlstrom, R. 1992. Multinational company strategy and host country policy. Scandinavian Journal of Management, 8: 3-13.

Obe, M. 2012. Tepco shareholders approve nationalization. Wall Street Journal, June 27: https:/www.wsj.com/articles/ SB10001424052702303561504577492331995963886.

Oh, C. H., \& Oetzel, J. 2011. Multinationals' response to major disasters: How does subsidiary investment vary in response to the type of disaster and the quality of country governance? Strategic Management Journal, 32: 658-681.

Oliver, C. 1992. The antecedents of deinstitutionalization. Organization Studies, 13: 563-588.

Olson, M. 1965. The logic of collective action: Public goods and the theory of groups. Cambridge, MA: Horvard University Press.

Olson, M. 1982. The rise and decline of nations. New Haven, CT: Yale University Press.

Osterloh, M., \& Frey, B. S. 2006. Shareholders should welcome knowledge workers as directors. Journal of Management and Governance, 10: 325-345.

Ostrom, E. 1990. Governing the commons: The evolution of institutions for collective action. New York: Cambridge University Press.

Ostrom, E. 2010. Beyond markets and states: Polycentric governance of complex economic systems. American Economic Review, 100: 641-672. 
Oxley, J. E. 1999. Institutional environment and the mechanisms of governance: The impact of intellectual property protection on the structure of inter-firm alliances. Journal of Economic Behavior \& Organization, 38: 283-309.

Pfeffer, J., \& Salancik, G. R. 1978. The external control of organizations: $A$ resource dependence perspective. Stanford, CA: Stanford University Press.

Porter, M. E. 1980. Competitive strategy: Techniques for analyzing industries and competitors. New York: Free Press.

Quelin, B., Cabral, S., Lazzarini, S., \& Kivleniece, I. 2014. Private scope in public-private partnerships: Institutional and experience determinants. Working paper, HEC Paris.

Rajan, R. 2012. Presidential address: The corporation in finance. Journal of Finance, 67: 1173-1217.

Rantete, J. 1998. The African National Congress and the negotiated settlement in South Africa. Pretoria: Van Schaik.

Reed, J. 2005. De Beers names first black executive. Financial Times, September 25: https:/www.ft.com/content/ 3ac7ca2a-30e8-11da-aclb-00000e2511c8.

Reich, R. B. 1984. Bailout: A comparative study in law and industrial structure. Yale Journal on Regulation, 2: 163-224.

Roe, M. J. 2013. Corporate short-termism-in the boardroom and in the courtroom. Business Lawyer, 68(4): 13-18.

Rousseau, D. M. 1989. Psychological and implied contracts in organizations. Employee Responsibilities and Rights Journal, 2: 121-139.

Schelling, T. 1960. The strategy of conflict. Cambridge, MA: Harvard University Press.

Scott, W. R. 1987. Organizations: Rational, natural and open systems. Englewood Cliffs, NJ: Prentice Hall.

Scott, W. R. 2008. Institutions and organizations: Ideas and interests. Thousand Oaks, CA: Sage.

Simon, H. A. 1947. Administrative behavior. New York: Macmillan.
Simon, H. A. 1952. A comparison of organization theories. Review of Economic Studies, 2: 40-48.

Simon, H. A. 1962. The architecture of complexity. Proceedings of the American Philosophical Society, 106: 467-482.

Smith, J. L. 1987. The common pool, bargaining, and the role of capture. Economic Inquiry, 25: 631-644.

Umbeck, J. 1977. A theory of contract choice and the California gold rush. Journal of Law and Economics, 20: 421-437.

Vernon, R. 1977. Storm over the multinationals: The real issues. Cambridge, MA: Harvard University Press.

Weaver, J. L. 1986. Unitization of oil and gas fields in Texas: A study of legislative, administrative, and judicial policies. Washington, DC: Resources for the Future.

Whetten, D. A. 1989. What constitutes a theoretical contribution? Academy of Management Review, 14: 490-495.

Williamson, O. E. 1985. The economic institutions of capitalism: Firms, markets, relational contracting. New York: Free Press.

Williamson, O. E. 1991a. Comparative economic organization: The analysis of discrete structural alternatives. Administrative Science Quarterly, 36: 269-296.

Williamson, O. E. 199lb. Economic institutions: Spontaneous and intentional governance. Journal of Law, Economics, and Organization, 7(Special Issue): 159-187.

Williamson, O. E. 1993. Transaction cost economics and organization theory. Industrial and Corporate Change, 2: 107-156.

Williamson, O. E. 1996. The mechanisms of governance. New York: Oxford University Press.

Williamson, O. E. 2000. The new institutional economics: Taking stock and looking ahead. Journal of Economic Literature, 38: 596-613.

Williamson, O. E. 2005. The economics of governance. American Economic Review, 95: 1-18.

Peter G. Klein (peter_klein@baylor.edu) is W. W. Caruth Chair and professor of entrepreneurship at the Hankamer School of Business, Baylor University, and professor of strategy and management at the Norwegian School of Economics. He received his Ph.D. from the University of California, Berkeley. His research focuses on the links between entrepreneurship, strategy, organization, and public policy.

Joseph T. Mahoney (josephm@illinois.edu) is the Caterpillar Chair of Business in the Gies College of Business at the University of Illinois at Urbana-Champaign. He received his Ph.D. in business economics from the Wharton School of Business at the University of Pennsylvania. His research focuses on organizational economics and strategic management.

Anita M. McGahan (amcgahan@rotman.utoronto.ca) is George E. Connell Chair in Organizations \& Society and professor of strategic management at the Rotman School of Management, University of Toronto. She received her Ph.D. from Harvard University. Her research focuses on private entrepreneurship in the public interest.

Christos N. Pitelis (Chris.pitelis@brunel.ac.uk) is dean of the College of Business, Abu Dhabi University, and university ambassador, Brunel University London. He received his $\mathrm{Ph} . \mathrm{D}$. in economics from the University of Warwick. His research is on international strategic organization and governance for sustainable value cocreation and capture. 